\title{
The Experience of Organizing Research and Project Activities of Bachelors of Pedagogical Education in Professional Training
}

\author{
Olga Sergeevna Naumova ${ }^{1 *}$, Maria Vladimirovna Boyarkina ${ }^{1}$, Irina Nikolaevna Kostina ${ }^{2}$, \\ Larisa Ilinichna Plotnikova ${ }^{3}$, Elena Alexandrovna Yuyshina ${ }^{4}$ \\ ${ }^{1}$ Transbaikal State University, Faculty of Psychology and Education, Department of Pedagogy, Chita, \\ Russia \\ ${ }^{2}$ Transbaikal State University, Faculty of History and Philology, Department of European Languages \\ and Linguodidactics, Chita, Russia \\ ${ }^{3}$ Transbaikal State University, Faculty of Psychology and Education, Department of Educational \\ Psychology, Chita, Russia \\ ${ }^{4}$ Transbaikal State University, Faculty of History and Philology, Department of Chinese Language, \\ Chita, Russia
}

\begin{abstract}
The article presents the experience of realization of the idea of the formation of project and research competence of future teachers during the organization of research and project activity of bachelors of pedagogical education. The purpose of the research: to justify the necessity to organize systematic project and research activities of students with the support of university professors and practicing teachers and to identify the prospects of solving this problem in the university educational process. Methods of research: study and analysis of scientific literature, normative documents, and Internet resources; comparative analysis; systematization; generalization of experience. The methods used by the authors are based on the synthesis of competence, systemic, and activity approaches. The authors propose to combine the acquisition of subject scientific knowledge and educational skills and abilities with the implementation, presentation, and defense of specific practice-oriented perspective pedagogical projects. The article presents the results of work for the period 2016-2020 with students of specializations 44.03.05 "Foreign languages (with two training specializations)" of full-time education and 44.03.01 "Foreign language education" of part-time education. The authors emphasize that strengthening the content of the subject disciplines (pedagogy, psychology, methodology of education and upbringing) and the inclusion of special additional research courses, modules, and practices in the training program of bachelors of education, and the development of the content of the pedagogical component of the state exam, demonstrating the appropriate level of formation of project and research competence, will solve the problem at a better level.
\end{abstract}

* Corresponding author: olga.naumova.72.72@mail.ru 


\section{Introduction}

Organization of project and research activities of bachelors of pedagogical education is a modern problem of higher education. It is conditioned by the requirements of the state policy in the sphere of education, disclosed by the content of such documents as the Professional Standard for Educator and Federal State Educational Standards (FSES) [1]. The professional activity of future educators is connected with the solution of such problems as identification of topical problems of upbringing, teaching, development and projecting the educational process, contributing to their solution; the creation of conditions for the development of a holistic, harmonious, versatile personality and a cohesive team; the implementation of various areas of educational activities in the classroom and after school hours; the creation of individual educational route of students, etc. [2-9]. The necessary conditions for solving professional tasks are the educator's ability to prepare, organize, and conduct scientific research and to identify effective ways of solving an independently identified problem. According to FSES of the third generation, students must be able to carry out project and research activities and determine the range of tasks within the given goal and choose the optimal ways of their solution. The formation of project and research competence is possible only under the condition of systematic project and research activities of students when integrating the subject and methodical direction of training with educational projecting. However, in the existing educational programs, these directions do not form a systemic unity. At the same time, the methodological and project areas are not sufficiently represented in professional training. Identification of the importance of each stage in the formation of project and research competence is a necessary condition for coordination of joint efforts of university professors, practicing teachers, and students in solving the common task of training bachelors of pedagogical education.

\section{Methods}

The organization of project and research activities involves the synthesis of various approaches, including the use of a practice-oriented approach combined with active and interactive methods of teaching, which, in turn, are characterized by the presence of nonstandard forms and means that determine the organization of educational space. The leading approaches are the following:

- competence approach - focuses on a set of general principles of goal setting, selection of the content of project and research activities, and qualitative evaluation of its results, expressed by the characteristics of the ability of bachelors of pedagogical education to act in various problem situations (V.A. Bolotov, A.A. Verbitsky, O.M. Kolomiets, V.A. Slastenin, etc. and foreign scientists - W. de Landsheer, D. McClelland, L. Spencer, etc.) [10-12].

- systemic approach - allows considering the created interaction of subjects of project and research activity as a system of interrelation and interdependence of functioning of all its components; based on the system analysis provides an opportunity to use the received experience in the professional activity of university professors, practicing teachers, and bachelors of pedagogical education (V.I. Zagvyazinsky, V.A. Karakovsky, L.I. Novikova, etc.) $[11,13,14]$;

- activity approach - supposes the realization of practical (transformative, applied) function, which consists in the improvement of pedagogical practice (the actual pedagogical reality) with the use of the complex of developed forms, methods, and means of upbringing, teaching, development, and pedagogical management, focused on the active and purposeful mastering of general cultural, general professional, and professional competences (L.S. Vygotsky, A.N. Leontyev, S.L. Rubinstein, N.I. Slobodchikov, etc.) [10, 14]. 
The practical orientation of the professional training of bachelors of pedagogical education is reflected in the improvement of the existing methods of teaching and learning, allowing students to increase their abilities and readiness for practical work, i.e. to combine the acquisition of scientific knowledge, educational skills and abilities with the implementation of specific practice-oriented promising pedagogical projects $[5,7,11,12$, 15 ,].

The scientific description of the project method was carried out by American teachers and philosophers $[5,7,11,12,15$,$] . D. Dewey, W. Kilpatrick, E. Collings, etc., offering to build$ education on an active basis, through expedient activities of the student, according to their personal interest in this knowledge. The works of S.T. Shatsky, V.V. Guzeev, I.A. Kolesnikova, and others are devoted to the questions of project activity in the Russian method. Project activities of students are directly related to their research work $[7,11,12$, 17-19].

The project and research activities of each student are carried out with the advice and support of the research supervisor, scholars, and qualified practicing teachers. The results of the joint activity are: a) presentation and defense of the psychological and pedagogical project by the graduate and defense of the graduate qualification work (GQW) at the final state certification (FSC); b) full-time and part-time participation of students and their supervisors in scientific and practical conferences, methodological seminars, and round tables; c) joint publications. The results of the individual project and research activities are pre-tested by students during the pre-diploma teaching practice and presented at scientific and practical conferences.

The final state examination has an integrated character; its model is presented in the article "Integrated model of the final state examination of bachelors of pedagogical education in a foreign language area" [12]. The themes of the pedagogical projects reveal the problems of the integral development of personality, development of a class group, development of personality in a collective, and different aspects of problems of general education $[1,5,15]$. The themes of GQW reflect the content of the activity of the teacher of a certain subject and solve the problems of personality development by means of a foreign language. To fulfill and protect the GQW, requirements have been developed to help a student. The complex approach to the evaluation of the educational achievements of a student allows judging about the integral preparation of a graduate for professional activity and the level of formation of project and research competence.

\section{Results}

The experience of organizing project and research activities of bachelors of pedagogical education was summarized from 2016 to 2020 based the work of students of specializations 44.03.05 "Foreign languages (with two training specializations)" of full-time education and 44.03.01 "Foreign language education" of part-time education.

At FSC for the period 2016-2020, 159 projects were presented and protected by bachelor graduates. The presented projects allow judging about the competence of the future educator and their readiness to solve specific pedagogical tasks. The analysis of the projects showed that, in general, students successfully cope with the set tasks but the lack of practical orientation of professional training, which affects the quality of project content, is a significant problem. When implementing and defending the projects, the graduates demonstrated the ability to navigate in the features of the educational space, to select the main concept when modeling the project, as well as to show a creative approach to building and presenting the product. At the same time, disadvantages were revealed: sketchiness in the analysis of the theoretical base and difficulties in drawing conclusions. 
The preparation for the defense of GQW by students was connected with the following difficulties: it is difficult for students to identify the object and subject of study, to select the methodological basis of the research, to make a clear correlation between the theory of the question and the practical refraction of the material. There is a necessity to introduce additional courses that reveal the methodological basis of the research.

Scientific and practical conferences have become an integral part of the organization of students' research activities: Zabaikalye Pedagogical Readings, Youth Scientific Spring; round tables ("My profession as a teacher", "The problem of personal freedom in pedagogy: history and modernity", "The problem of the harmony of scientific and spiritual in the professional training of future educators", etc.), which took place within the Festival of Science with the involvement of students in active research activities [1, 19, 20]. At conferences, students present their ideas, which become the basis of projects. Besides, students take part in the student scientific and practical conference "Philological education and the modern world"; every year this conference is attended by $50 \%$ of part-time education students and $85 \%$ of full-time education students. In the sections, participants test GQW and present reports on the practical part of graduation works.

\section{Discussion}

As a result of the research, it became clear that there is a necessity to include additional modules and courses in the FSES 3++ Curriculum aimed at forming project and research competence and strengthening the role of the practical orientation of training future educators.

According to the types of (project and research) professional activity, a graduate should have several professional competences, the formation of which is carried out when mastering a set of subject disciplines in accordance with the curriculum for the specialization and the year of the beginning of training $(2016,2017,2018)$. In accordance with the competence matrix for the curriculum, the formation of project and research competences by pedagogical disciplines is possible only with the consulting support of the production practice (pedagogical). At the same time, learning how to solve problems of upbringing, spiritual and moral development, and socialization of students, their achievement of training results (personal, metasubject, subject), and professional self-determination is not enough without acquiring the skills of projecting educational programs and individual educational routes and creating a trajectory of their own professional growth and personal development. Besides, project and research activities in total imply the analysis of possibilities of the educational environment, choice of modern forms, methods, and technologies of activity (educational and extra-educational), and management of educational and research activities of students. In this regard, questions about increasing the participation of educators and psychologists in the formation of designated competences in teaching subject disciplines, disciplines of choice, organization and conduct of practices and development of the content of the pedagogical component of the state exam, demonstrating the appropriate level of formation of project and research competence, become relevant.

\section{Conclusion}

The conducted research allowed us to judge about the prospects of solving the problem of organizing project and research activities in the process of professional training, the result of which should be the project and research competence formed in future educators. An important condition is the interrelation of theoretical knowledge, practical skills, and experience in creative activity. Strengthening the content of the subject disciplines 
(pedagogy, psychology, methodology of education and upbringing) associated with the solution of this problem and the inclusion of special additional research courses, modules, and practices will allow solving this problem at a better level.

\section{References}

1. O.S. Naumova, Social partnership as a factor in the training of future teachers for the spiritual and moral education of schoolchildren, Orthodoxy and Society: facets of interaction, Materials of II International scientific-practical conf. Transbaikal. state unty, Chita, Russia (2018)

2. M. Martin-Raugh, R.J. Tannenbaum, C.M. Tocci, C. Reese, Teaching and Teacher Education 59, 414-419 (2016)

3. C. Walker, A. Gleaves, Teaching and Teacher Education 54, 65-76 (2016)

4. F.A.J. Korthagen, Teaching and Teacher Education 20(1), 77-97 (2004)

5. M. Spear, R.B. da Costa, Teaching and Teacher Education 69, 202-209 (2018)

6. R. Nash, Teaching and Teacher Education 19(7), 755-767 (2003)

7. K. Ruthven, S. Hennessy, S. Brindley, Teaching and Teacher Education 20(3), 259-275 (2004)

8. S.F. Shawer, Teaching and Teacher Education 63, 296-313 (2017)

9. Z. Zhanga, J. Lib, F. Liuc, Z. Miaoc, Teaching and Teacher Education 59, 146-158 (2016)

10. O.M. Kolomiyets, The pedagogical concept of teaching based on the competenceactivity approach: Doctoral dissertation (Sechenov First Moscow State Medical University, Moscow, 2018)

11. N. G. Lavrentyeva, O. S. Naumova, Continuity in the Formation of Design and Research Competence in Bachelor Students of Preschool Education in the Process of Studying Pedagogical and Methodical Disciplines, in International Scientific and Practical Conference on Education, Health and Human Wellbeing, 26-28 November, Narnaul (2019) Available at: https://www.atlantis-press.com/proceedings/iceder-19/articles

12. O.S. Naumova, T.N. Klimenko, Pedagogicheskiy IMIDZH, 1, 104-124, (2018).

13. V.I. Zagvyazinskiy, Pedagogika, 1, 12-18, (2016).

14. Ye.N. Stepanov, L.M. Luzina, To a teacher on modern approaches and concepts of education. (TTS Sfera, Moscow, 2003).

15. T.N. Klimenko, I.N. Kostina, S.N. Mikhaleva, O.S. Naumova, O.B. Ganina, The final state exam of the bachelor of teacher education: textbook (ZabGU, Chita, 2017)

16. I.A. Kolesnikova, M.P. Gorchakova-Sibirskaya, Pedagogical Design (Akademiya, Moscow, 2007)

17. I.N. Kostina, Procedia-Social and Behavioral Sciences 191, 1489-1495 (2015)

18. I.N. Kostina, Bulletin of the Khakass State University named after N.F. Katanov 9, 9093 (2014)

19. O.S. Naumova, Uchenyye zapiski ZabGU. Seriya "Pedagogicheskiye nauki" 5(5), 6171 (2018)

20. O.S. Naumova, Dukhovno-nravstvennoye vospitaniye 4, 10-27 (2018) 